\title{
Biomarker Indicator
}

National Cancer Institute

\section{Source}

National Cancer Institute. Biomarker Indicator. NCI Thesaurus. Code C93515.

Specifies whether an entity is considered a biomarker. 